\title{
DIETARY TREATMENT OF HYPERTENSION. CLINICAL AND METABOLIC STUDIES OF PATIENTS ON THE RICE- FRUIT DIET
}

\author{
BY VINCENT P. DOLE, LEWIS K. DAHL, GEORGE C. COTZIAS, HOWARD A. EDER, \\ AND MARGARET E. KREBS
}

(From The Hospital of the Rockefeller Institute for Medical Research, New York City)

(Submitted for publication January 4, 1950; accepted, June 12, 1950)

This report is based on a study of six patients who were treated for hypertension by means of the rice-fruit diet of Kempner (1). During the six months of study with the patients in continuous residence on a metabolic ward observations were made to follow the evolution of both clinical and metabolic changes.

The purpose of this study was the analysis of certain aspects of the necessity and the sufficiency of the rice-fruit program as applied to selected patients in a controlled environment. To this end evidence will be presented to demonstrate that objective clinical improvement actually occurred in these patients while they were under detailed metabolic observation.

Whether the high incidence of clinical improvement observed was due to the selection of relatively young and uncomplicated hypertensive subjects or due to the detailed supervision of dietary intake or even whether the sheltered environment of a metabolic ward may have contributed to the favorable effects was not investigated. These considerations, although pertinent to the general problem of dietary treatment (2), are not directly relevant to the present issue of association between clinical and metabolic change.

\section{Procedure}

While on the metabolic ward the patients remained ambulatory but with activities limited to light hand work. The environmental temperature remained in the comfort range during the period of study. No patient was aware of sweating at any time except when thermal sweating was induced for the purpose of collection of sweat.

The recumbent blood pressure of each patient was measured by the same physician each morning following a 20 minute rest period. A mercury sphygmomanometer was used; systolic pressure was read at the beginning and diastolic pressure at the cessation of sound. The fundi were examined after full dilatation weekly by three observers, and a map made of any lesions seen. Electrocardiographic tracings were obtained approximately every four weeks. Chest X-ray films, exposed at two meter distance for determination of heart size, were taken every two to four weeks. Blood samples of $50 \mathrm{cc}$. volume were taken weekly.

Preliminary period (14-30 days). During this time the patient became adjusted to ward procedure, with unrestricted hospital diet.

Period I (70-95 days). The initial rice diet consisted of only $90 \mathrm{gm}$. of rice per day with the fruits and fruit juices admitted in Kempner's regimen and a vitamin supplement. ${ }^{1}$ The patients were allowed to select their levels of caloric intake through variation of sugar and fruit consumption. The rice intake, however, was held constant. On this schedule the patients received a calculated protein intake of $20-25 \mathrm{gm}$. per day, of which 7 gm. were from rice.

After the patients had been on this diet for intervals which varied from 18 to 56 days as a result of starting Period $I$ at different times, they all were changed to a

1 The calculated amounts of certain vitamins provided by a typical daily rice-fruit intake are: vitamin $\mathrm{A}, 115$ I.U. ; thiamin, $1.1 \mathrm{mg}$. ; riboflavin, $0.25 \mathrm{mg}$. ; nicotinic acid, $18 \mathrm{mg}$.; pantothenic acid, $0.5 \mathrm{mg}$.; vitamin C, $325 \mathrm{mg}$. According to usual standards the provision of riboflavin and pantothenic acid would be inadequate and the quantities of vitamin $\mathrm{A}$ and thiamin appear undesirably low. The patients therefore received additional daily vitamin intake in two multivitamin capsules ("Unicaps," Upjohn). According to the manufacturer's data these two capsules provided the following supplementary intakes: vitamin A, 10,000 I.U.; thiamin, 5 mg.; pyridoxin $\mathrm{HCl}, 1 \mathrm{mg}$.; vitamin C, $75 \mathrm{mg}$; vitamin D, 1,000 U.S.P. units. Although an adequate provision appears to have been made for the more familiar vitamin factors, it is possible that other factors, such as other components of the vitamin B complex, may have been lacking. However, none of the patients during five months of this diet presented any signs-epithelial, neural or metabolic-to make one suspect vitamin deficiency.

Mineral intake was probably deficient in some respects. Calcium intake was only about $140 \mathrm{mg}$. per day (calculated). The calculated values of other elements were: $\mathrm{Mg}, 175 \mathrm{mg}$. per day; $\mathrm{Fe}, 8 \mathrm{mg}$. per day; Cu, $1 \mathrm{mg}$. per day ; S, 250 per day. The determined intake of phosphorus was $425 \mathrm{mg}$. per day. Of this, a calculated $150 \mathrm{mg}$. per day was included as phytic acid phosphorus which might not only have been unavailable in itself, but also may have further limited the effective ration of divalent cations. 
diet containing $250 \mathrm{gm}$. of rice per day with reduced amounts of fruit. On this diet the protein intake was calculated to be about $25 \mathrm{gm}$. per day, $20 \mathrm{gm}$. of which came from the rice. Sugar intake was adjusted to provide the same total caloric intake as before the change and control of subsequent caloric variation again was left with the patients. Fluid intake supplementary to the water contained in the cooked rice and fruit, which had been $1,200 \mathrm{cc}$. per day on the initial program, was at this time reduced to $1,000 \mathrm{cc}$. per day, thereby keeping the total daily fluid intake approximately constant.

After 31 days on this program the patients were allowed to choose a combination of fruits and a quantity of sugar representative of their diets at the time and

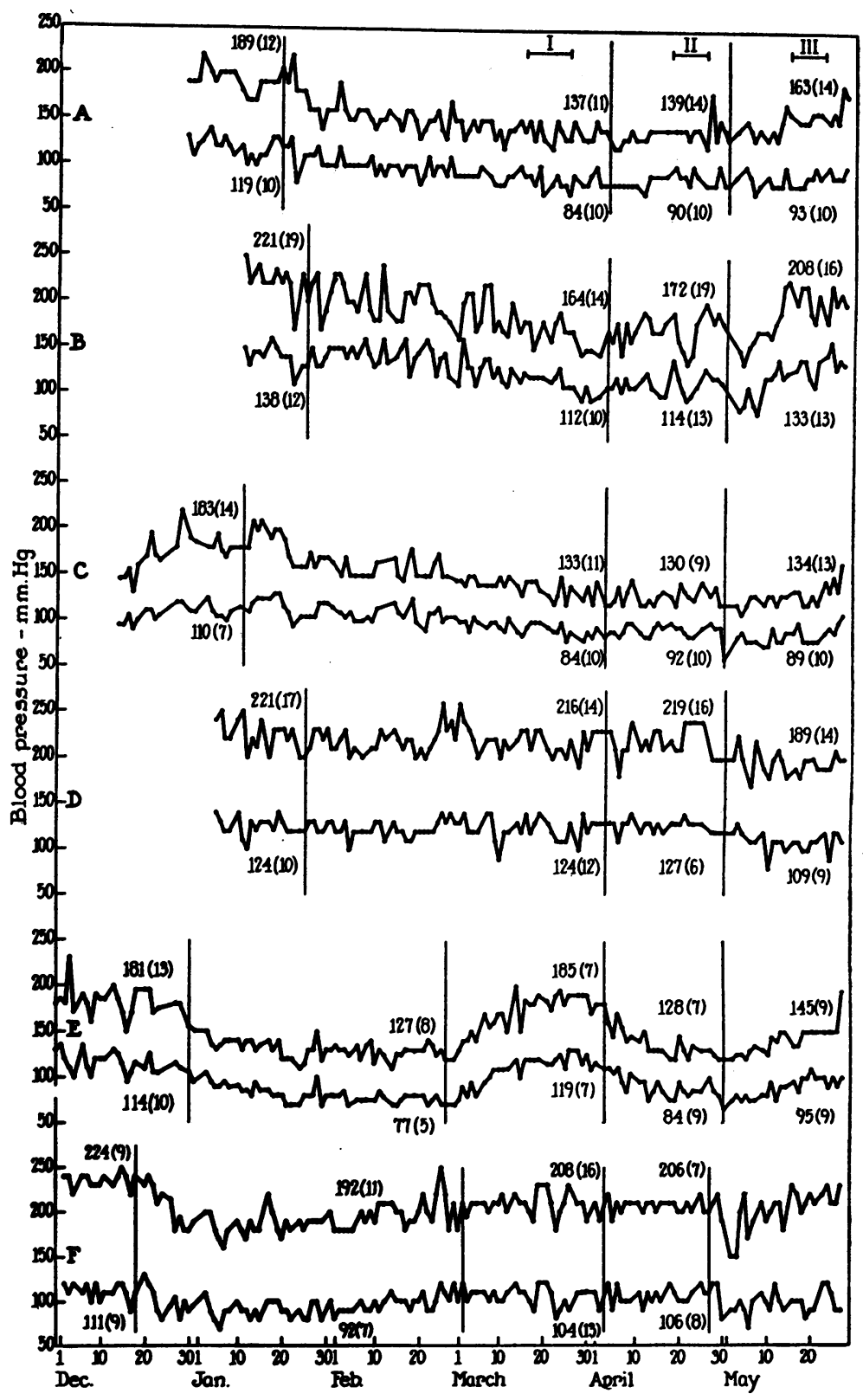

Fig. 1. Morning Blood Pressure Values

Vertical lines indicate changes in regimen, the first in each case being the start of the rice diet. The means and the standard deviations of the last 14 values of each period are shown. I, II and III at the top show the intervals during which balance studies were made. 
were then fed this menu without variation for the next 17 days during which time Balance I observations were made.

Period II (28 days). Diets remained the same during this period except for the supplementary intake of $2.5 \mathrm{gm}$. per day of ammonium chloride. Two weeks were allowed for adjustment; the patients were then fed the same invariant menus as in the first balance and Balance II observations were made.

Period III (27 days). In this period the ammonium chloride was replaced by sodium chloride, $2.5 \mathrm{gm}$. per day. After two weeks the invariant menus of Balance I again were fed and Balance III observations were made.
Exceptions. Patient $\mathrm{B}$, initially obese, was restricted to about 1,900 calories per day. Patient C, who was a very small woman, found the bulk of $250 \mathrm{gm}$. per day of rice uncomfortably large; her ration was reduced to 200 gm. per day during Period I and to $175 \mathrm{gm}$. per day in Periods II and III. Patient E had shown such a prompt and marked reduction in blood pressure as to make us suspect that we were observing merely the effects of suggestion or of the hospital routine in a person with labile blood pressure. During the last month of Period I (labeled $I_{b}$ ) she received capsules containing $10 \mathrm{gm}$. per day of sodium chloride; the increase in blood pressure was unequivocal and, we believe, not due to sug-

TABLE I

Clinical data

\begin{tabular}{|c|c|c|c|c|c|c|c|c|}
\hline \multirow{2}{*}{ Patient } & \multirow{2}{*}{ Period } & \multicolumn{2}{|c|}{$\begin{array}{c}\text { Approximate } \\
\text { intake }\end{array}$} & \multicolumn{2}{|c|}{$\begin{array}{c}\text { Blood pressure } \\
\text { averagesand } \\
\text { standard deviations }\end{array}$} & \multicolumn{2}{|c|}{$\begin{array}{c}\text { Chest film } \\
\text { measurements }\end{array}$} & \multirow{2}{*}{$\begin{array}{c}\text { Retinal } \\
\text { hemorrhage } \\
\text { and } \\
\text { exudate }\end{array}$} \\
\hline & & $\mathrm{Na}$ & $\mathrm{Cl}$ & Systolic & Diastolic & $\begin{array}{c}\text { Heart } \\
\text { diameter }\end{array}$ & $\begin{array}{c}\text { Chest } \\
\text { diameter }\end{array}$ & \\
\hline \multirow[t]{3}{*}{ A } & $\mathbf{P}$ & meq./day & meq./day & $\begin{array}{l}m m . H_{g} \\
189(12)\end{array}$ & $\begin{array}{c}m m . H_{g} \\
119(10)\end{array}$ & $\begin{array}{l}m m . \\
143\end{array}$ & $\begin{array}{l}m m . \\
313\end{array}$ & 0 \\
\hline & II & $\begin{array}{l}2.0 \\
1.7\end{array}$ & 55 & $\begin{array}{l}137(11) \\
139(14)\end{array}$ & $\begin{array}{l}84(10) \\
90(10)\end{array}$ & $\begin{array}{l}127 \\
119\end{array}$ & $\begin{array}{l}312 \\
309\end{array}$ & $\begin{array}{l}\mathbf{0} \\
\mathbf{0}\end{array}$ \\
\hline & III & 45 & 48 & $163(14)$ & $93(10)$ & 133 & 302 & 0 \\
\hline \multirow[t]{3}{*}{ B } & $\mathbf{P}$ & & & $221(19)$ & $138(12)$ & 170 & 340 & + \\
\hline & II & $\begin{array}{l}2.5 \\
1.9\end{array}$ & $\begin{array}{c}6.4 \\
54\end{array}$ & $\begin{array}{l}164(14) \\
172(19)\end{array}$ & $\begin{array}{l}112(10) \\
114(13)\end{array}$ & $\begin{array}{l}140 \\
140\end{array}$ & $\begin{array}{l}331 \\
333\end{array}$ & + \\
\hline & III & 45 & 48 & $208(16)$ & $133(13)$ & 145 & 326 & 0 \\
\hline \multirow[t]{2}{*}{ C } & $\mathbf{P}$ & & & $183(14)$ & $110(7)$ & 120 & 242 & + \\
\hline & $\begin{array}{l}\text { II } \\
\text { III }\end{array}$ & $\begin{array}{l}2.0 \\
1.8 \\
45\end{array}$ & $\begin{array}{l}4.2 \\
53 \\
47\end{array}$ & $\begin{array}{l}133(11) \\
130(9) \\
134(13)\end{array}$ & $\begin{array}{l}84(10) \\
92(10) \\
89(10)\end{array}$ & $\begin{array}{l}101 \\
103 \\
112\end{array}$ & $\begin{array}{l}240 \\
242 \\
242\end{array}$ & $\begin{array}{l}\mathbf{0} \\
\mathbf{0} \\
\mathbf{0}\end{array}$ \\
\hline \multirow[t]{2}{*}{ D } & $\begin{array}{l}\mathbf{P} \\
\text { I } \\
\text { II }\end{array}$ & $\begin{array}{l}2.1 \\
1.5\end{array}$ & 52 & $\begin{array}{r}221(17) \\
216(14) \\
219(16)\end{array}$ & $\begin{array}{l}124(10) \\
124(12) \\
127(6)\end{array}$ & $\begin{array}{l}131 \\
124 \\
120\end{array}$ & $\begin{array}{l}293 \\
280 \\
286\end{array}$ & $\begin{array}{l}+ \\
0 \\
0\end{array}$ \\
\hline & III & 45 & 47 & $189(14)$ & $109(9)$ & 128 & 288 & 0 \\
\hline \multirow[t]{5}{*}{$E$} & $\mathbf{P}$ & & & $181(13)$ & $114(10)$ & 130 & 243 & + \\
\hline & $I_{\mathrm{a}}$ & 2.3 & 6.0 & $127(8)$ & $77(5)$ & 122 & 243 & 0 \\
\hline & $\mathbf{I}_{\mathbf{b}}$ & 200 & 200 & $\cdot 185(7)$ & $119(7)$ & 140 & 250 & 0 \\
\hline & II & 1.9 & 52 & $128(7)$ & $84(9)$ & 120 & 243 & 0 \\
\hline & III & 45 & 48 & $145(9)$ & $95(9)$ & 127 & 243 & 0 \\
\hline \multirow[t]{3}{*}{ F } & $\mathbf{P}$ & & & $224(9)$ & $111(9)$ & 151 & 238 & +++ \\
\hline & $\mathbf{I}_{\mathbf{n}}$ & 1.5 & 5.4 & $192(11)$ & $92(7)$ & 125 & 245 & +++ \\
\hline & $\underset{\text { II }}{\mathbf{I}_{b}}$ & $\begin{array}{l}5.1 \\
5.0\end{array}$ & $54^{5.4}$ & $\begin{array}{l}208(16) \\
208(7)\end{array}$ & $\begin{array}{l}104(13) \\
106(8)\end{array}$ & $\begin{array}{l}135 \\
136\end{array}$ & $\begin{array}{l}250 \\
263\end{array}$ & $\begin{array}{l}++ \\
++\end{array}$ \\
\hline
\end{tabular}

Blood pressure averages and standard deviations were calculated from the last 14 morning values of each period. Asterisks between consecutive averages indicate changes regarded as significant. 
gestion. Patient $F$, the only subject with renal limitation, received an increased amount of sodium during the last month of Period I (labeled $I_{b}$ ) by the addition of $300 \mathrm{mg}$. per day of sodium bicarbonate which raised her sodium intake from 1.5 to a total of 5 meq. per day.

Blood pressure. The detailed variations of blood pressure during the study are shown in Figure 1 and the mean values with their standard deviations are shown in Table I. Each mean value was calculated from the last 14 days of its period, thus largely omitting transitional data. Changes in the mean values were considered significant if greater than $15 \mathrm{~mm}$. $\mathrm{Hg}$ systolic or $10 \mathrm{~mm}$. $\mathrm{Hg}$ diastolic. ${ }^{2}$

Changes between successive mean values which are significant by these criteria are indicated in the table by an asterisk interpolated between the two values. It will be seen that a decrease during Period I was observed in both the systolic and the diastolic blood pressures of five out of the six patients-all but Patient D. In three patients the blood pressure became normal. None of the patients showed any further significant changes in blood pressure on administration of ammonium chloride in Period II except $\mathrm{E}$ whose high sodium intake of Period $I_{b}$ was discontinued in Period II. During Period III, under the administration of moderate amounts of sodium chloride, three patients out of five developed an increased systolic blood pressure and two of the five, an increased diastolic pressure as well. These observations may be summarized by noting that in five of the six patients all significant changes in blood pressure were correlated with the changes in sodium intake and were independent of the chloride intake. The behavior of the remaining patient (D) suggests that other factors must also be at work; she actually had a reduction in blood pressure when the sodium intake was increased in Period III.

\footnotetext{
2 The probability for chance difference of 15 or greater is less than .05 if the standard deviation $(\sigma)$ is 20 and less than $10^{-4}$ if $\sigma=10$. For diastolic pressure the probability of difference greater than 10 is about .04 if $\sigma=13$ and $10^{-8}$ if $\sigma=5$. These calculations are based upon Fisher's $t$ test (8) as applied to the difference of means of two aggregates each of 14 values and with the same standard deviation.

The requirements that changes exceed $15 \mathrm{~mm}$. Hg systolic or 10 diastolic to be considered significant thus are conservative ones which tend to exclude changes of possible importance rather than risk inclusion of doubtful effects.
}

There were no consistent changes in the variability of blood pressure as measured by the standard deviations.

It is concluded from these data that significant changes in the average resting morning blood pressures had been induced.

Heart size. Table I shows the maximum transverse diameter of the heart and the internal chest diameter measured in a standard two meter chest film obtained during each period covered by a blood pressure mean. It may be seen that in 11 of the 12 instances of significant change in mean blood pressure a corresponding change in heart size was observed. This association between heart size and mean blood pressure is presented graphically in Figure 2 where the circles are drawn to suggest the limits of confidence that may be attached to localization of the enclosed points.

The correlation between mean morning blood pressure and heart size suggests that changes in morning blood pressures actually reflected changes in the integrated pressure of the entire day.

Fundi. On admission Patient $\mathrm{F}$ was barely able to read large print and was seen to have numerous retinal hemorrhages, many areas of exudate, tortuosity of the arterioles and blurring of the discs without measureable elevation. Despite a rather poor response to treatment as measured by decrease of blood pressure she had a striking reduction in retinal lesions with return of her ability to read.

At various times during the first month $\mathrm{Pa}$ tients $\mathrm{B}, \mathrm{C}, \mathrm{D}$, and $\mathrm{E}$ were found to have areas of retinal hemorrhage or exudate. None could be found in careful weekly examinations during the last two months.

Electrocardiogram. Tracings, including chest leads, were made at least once per month. Three patients had left axis deviation which persisted in all subsequent tracings. Four of the six patients had low or inverted $T$ waves in the first two months; at the time of discharge all $\mathrm{T}$ waves had become normal.

\section{Procedure}

During the last two weeks of the second, third, and fourth periods detailed balance observations were made. A single day's menu was chosen for each patient with care that it be typical of the rice, fruit, and caloric intake of that patient at the time of the first balance study. Thereafter the same daily menu was given to each pa- 
tient on every day of all three balance studies. Diet analyses were made for each of the three balance studies. A complete day's diet of each patient was prepared for analysis by homogenization with $7 N$ sulfuric acid and dilution to 6.5 liters volume so that samples could be taken volumetrically. All balance data were calculated from determined intakes and outputs.

Urines were pooled for intervals of three days. Concentrated hydrochloric acid ( 1 per cent by volume) was added to one aliquot; toluene was used for the sample saved for chloride analysis. Stools were passed directly into clean Mason jars which were capped and kept in the ice box. Stools, marked alternately for intervals with carmine $\left(0.8 \mathrm{gm}\right.$.) and charcoal (15 gm.), ${ }^{8}$ were

3 The use of charcoal was unwise since subsequent analysis showed that it contained $142 \mathrm{mg}$. of phosphorus and 0.35 meq. of sodium per gram. Because of this complication phosphorus balance data are omitted. The sodium dose provided by the charcoal marker given in the second period was not a serious complication since comparison of the stool sodium concentrations showed that the charcoal carried out into the stools one to three of the later sorted out and individually homogenized with approximately $250 \mathrm{cc}$. of $7 \mathrm{~N}$ sulfuric acid. A mixer cap which replaced the regular Mason jar screw cap allowed this homogenization to be accomplished as a closed procedure without transfer from the original jar. This was a considerable esthetic advance over earlier open techniques. After blending, the samples for one interval were pooled into a two liter volumetric flask for subsequent sample by pipette.

\section{Methods}

Nitrogen was determined by the titrimetric macroKjeldahl method using the digestion mixture of Hiller, Plazin and Van Slyke (3). For the purpose of the next section in which an estimate will be made of cumulative

five milliequivalents of sodium contained in the dose. Therefore the effective sodium intake of the patients during the balance observations averaged only about onethird of a milliequivalent per day greater than otherwise.

4 Osterizer Mixer Model 10; John Oster Manufacturing Company.

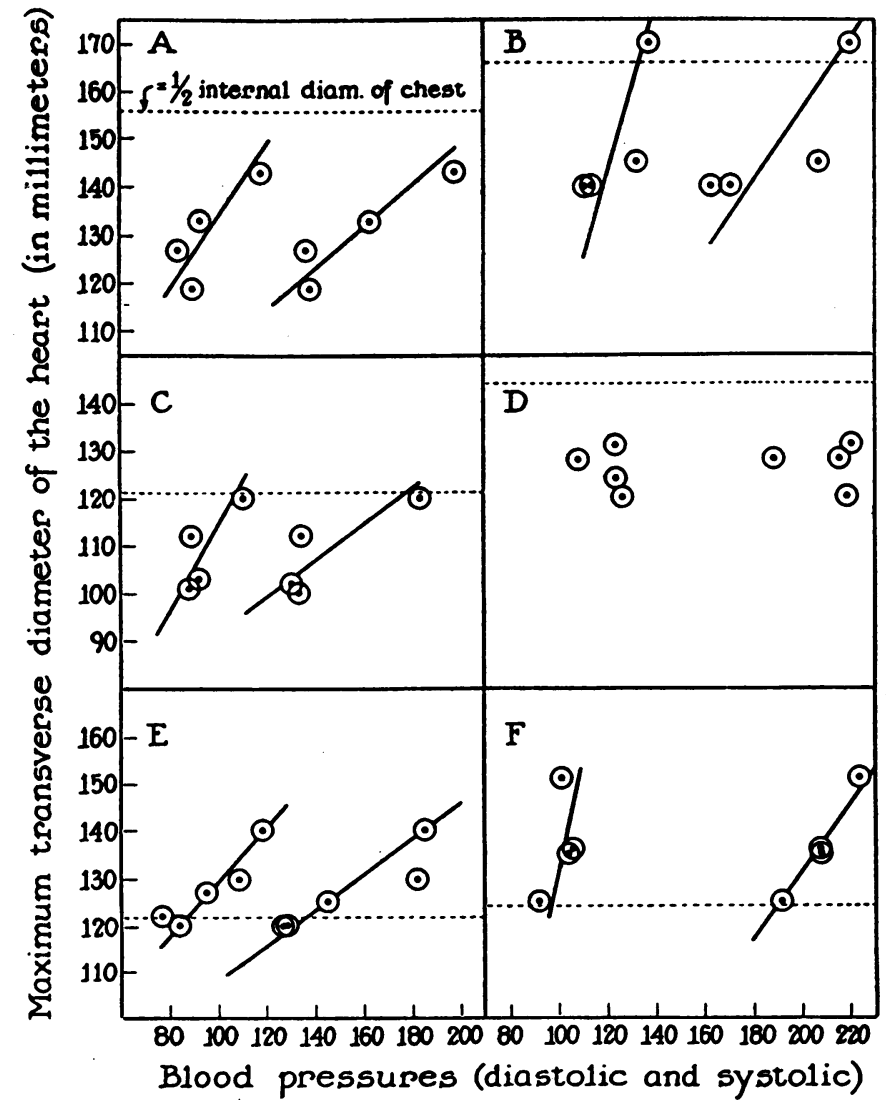

Fig. 2. Relation Between Heart Size (Maximum Transverse Diameter on Two Meter Chest Film) and the Mean Systolic and Diastolic Blood Pressures of the Corresponding Period

The dotted horizontal line is drawn at a value of one-half the internal diameter of the chest. 
analytical errors an uncertainty of 1 per cent was assigned to each datum.

Sodium and potassium were estimated with a Model 52A Perkin-Elmer flame photometer using an internal lithium standard. Plasma and urine were diluted to the desired working concentrations. The diet and stool samples, already acidified with sulfuric acid, were hydrolyzed on a steam bath for 12 to 48 hours, diluted to volume and filtered through washed cotton.

Potassium was present in relatively large amounts in all material; its analysis presented no problem. Sodium, however, required special care because of its low concentration. Frequent measurements were made on comparable standards during the course of analysis and sufficient repeated measurements were made on different days with the same material to assure ourselves of the reproducibility of the method. An uncertainty of 3 per cent was assigned to each datum.

Chloride was measured by the silver iodate method of Sendroy (4) as modified by Van Slyke and Hiller (5). For the low chloride urines a further slight modification was necessary: 25 cc. samples of urine, rather than the $5 \mathrm{cc}$. samples which usually suffice, were mixed with $5 \mathrm{cc}$. of $0.75 \mathrm{~N} \mathrm{H}_{8} \mathrm{PO}_{4}$, thus making the final volume and acid concentration the same as usual but the urine content five times as great. The analyses were done in a $20^{\circ} \mathrm{C}$. constant temperature room. With these precautions, the solubility correction for $\mathrm{AgIO}_{3}$ was no more than 10 per cent of the titration values and recoveries from dilute standards were satisfactory. To each datum was assigned an uncertainty of 2 per cent.

For blood and urine $p H$ measurements, a glass electrode reliable to about \pm 0.02 was set up in an incubator room at $38^{\circ}$. Blood was taken into a $20 \mathrm{cc}$. syringe wet with a saline solution of heparin; part was delivered under oil for determination of $\mathrm{CO}_{2}$ content (6); the remainder was read immediately in the glass electrode. Urine was passed directly into tubes $7^{\prime \prime} \times 1^{\prime \prime}$ and the $\mathrm{pH}$ was read immediately in the glass electrode.

Plasma volume was estimated with Evan's blue dye with measurement of the plasma dye concentration at ten minutes as recommended by Gregersen (7).

\section{Evaluation of errors}

The significance of a given balance datum cannot be estimated from the final result even when the accuracy of the analytical method is known, since a relatively small difference between large values is obviously less well defined than the same difference obtained from smaller primary values. In practice, each sample for chemical analysis was diluted so as to bring the concentration within a rather narrow working range optimal for the method. Because the concentrations at the time of analysis were similar the estimations of the quantities of any given element were affected by a fairly constant percentage uncertainty. Likewise the other manipulations such as dilution, sampling and digestion also tended to introduce uncertainty on a percentage rather than on an absolute basis. Therefore, to each method a value has been assigned which seems to represent best the percentage uncertainty associated with any analytical result. This value was then taken arbitrarily as the coefficient of variation for the procedure, measuring an assumed normal distribution of errors about the true mean. To estimate the cumulative effect of this uncertainty in a final balance datum, the principle that the variance (square of the standard deviation) of an algebraic sum is the sum of the variances of all the terms (8) is employed.

Each balance datum is based on five terms: intakes of the element in diet and in medicines (positive terms) and outputs in urine, stools and in blood samples taken for analyses (negative terms). To the estimated loss in a blood sample an uncertainty of 10 per cent is assigned. These considerations lead to the following formula for the variance $\sigma^{2}$ of the balance of any element due to analytical errors :

$$
\sigma^{2}=\mathrm{e}^{2}\left(d^{2}+m^{2}+u^{2}+s^{2}\right)+.01 b^{2},
$$

where $e$ is the percentage error assigned to the analysis of the element in question and the symbols $d, m, u, s$, and $b$ indicate the average daily quantities entering the calculation as diet, medicine, urine, stool and blood, respectively.

In addition to the purely analytical errors, some account must be taken of the variation in daily intake. This may be estimated for nitrogen by comparing the analytical values obtained for the diet nitrogen content in the three separate balance studies, in the cases of four patients ( $A$, $B, D, E)$. Each of these patients should have had the same diet repeated in the consecutive balance studies. Considered as an aggregate these values have a coefficient of variation of 6 per cent. This must be an upper limit to the actual variations during a single balance experiment since it was necessary to use different lots of rice and fruits in the different experiments. For the sake of estimation it will be assumed that half of the variability (3 per cent) was due to variation of daily intake. As an allowance for the probable fluctuation of nitrogen intake within any single balance study the term $(.03)^{2} \mathrm{~d}^{2}$ was added to the estimated analytical variance. For the ions no additional term was included since the diet was at all times low in these elements; their variation is thus to some extent underestimated.

An average standard deviation $\sigma$ of the daily balance, so calculated, is given in Table II with the average balance of each element in each of the three balance experiments. It was not realized during the experiments, but became apparent on analysis of the data, that in some cases almost half of the total variance was contributed by the taking of blood samples. This occurred when the outputs of sodium and chloride by sampling were of the same order of magnitude as urinary and fecal outputs. Blood sampling also caused appreciable loss of precision in all nitrogen balance data.

In addition to the analytical uncertainties it is to be remembered that cutaneous losses of the elements are not included in the balances. The environment was fairly constant, however; it is hoped that such effects were sufficiently constant not to affect the estimated variability. 


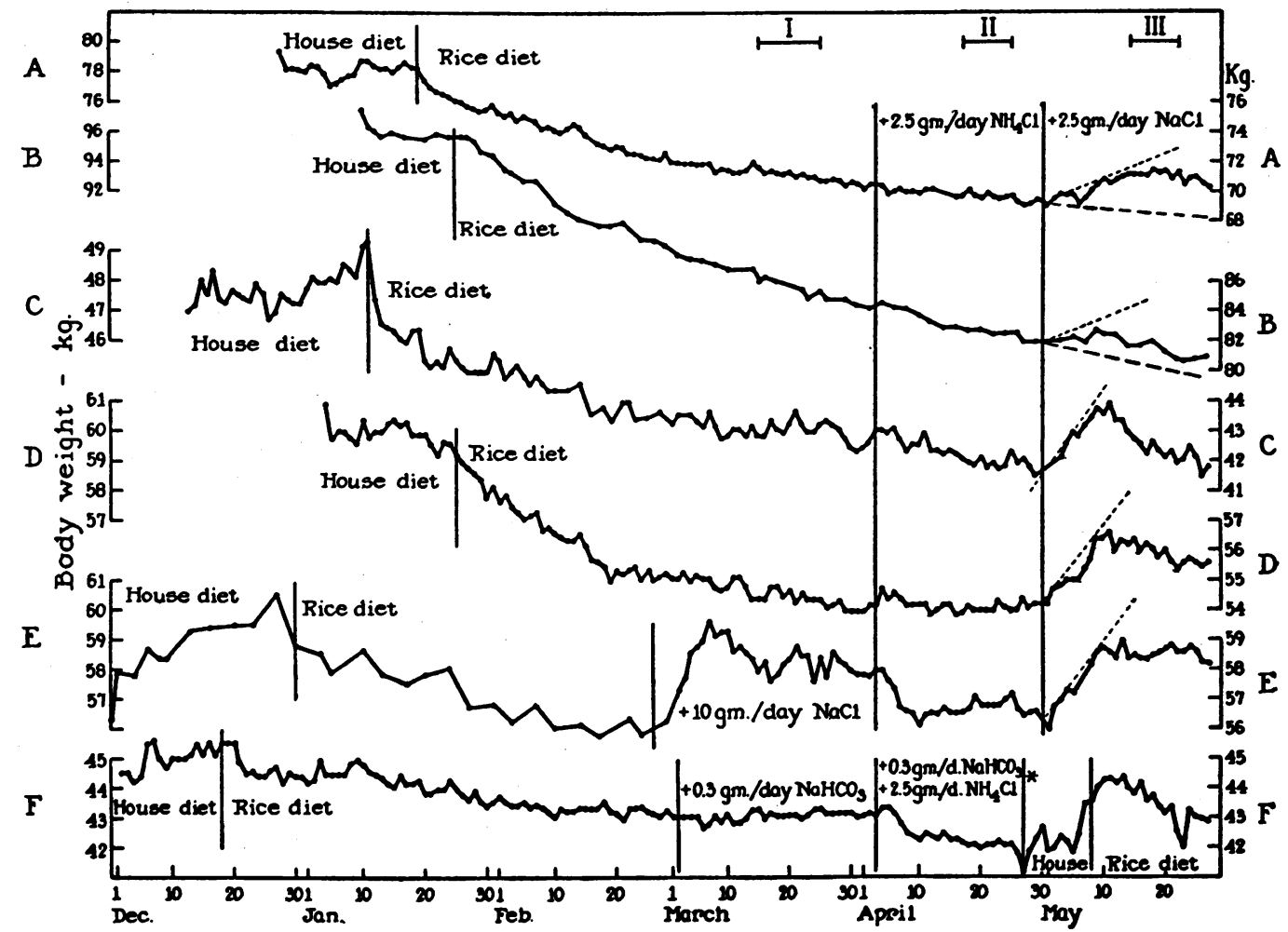

Fig. 3. Weight Curves of the Six Patients

Change of regimen is in each case marked by a vertical line. At the times indicated by the first vertical lines the rice diet was instituted. This was continued for the remainder of the study, subsequent changes being only of electrolyte supplements. I, II and III at the top of the graph show the intervals during which balance measurements were made.

In one patient $(C)$ a normal menstrual period which occurred during each of the balance experiments led to unmeasured losses.

\section{Body weight}

\section{Analysis of data}

Analysis of the metabolic data is perhaps best begun by a study of the weight changes induced by the change of diet to the rice-fruit regimen.
Following the change, all patients lost weight rapidly at first but later arrested the loss so as to approach a new steady weight at a lower level. The caloric intakes of all patients except $B$ were voluntarily lowered during the early phase of rapid weight loss and were increased later as the new weight equilibrium was approached. Patient B was on a fixed intake of 1,900 calories per day as

TABLE II

Weight loss data

\begin{tabular}{|c|c|c|c|c|c|c|c|c|}
\hline Patient & Age & Ht. & $\begin{array}{l}\text { (a) } \\
\text { Ideal } \\
\text { wt. }\end{array}$ & $\begin{array}{c}\text { (b) } \\
\text { Initial } \\
\text { wt. }\end{array}$ & $\begin{array}{c}\text { (c) } \\
\text { Final } \\
\text { wt. } \\
\text { (calculated) }\end{array}$ & $\begin{array}{l}\text { (a) } /(b) \\
\frac{\text { Initial }}{\text { Ideal }}\end{array}$ & $\begin{array}{l}\text { (b) }-(c) \\
\text { Wt. loss }\end{array}$ & $\begin{array}{c}\text { Half-time } \\
\text { of loss }\end{array}$ \\
\hline $\begin{array}{l}\mathbf{A} \\
\mathbf{B} \\
\mathbf{C} \\
\mathbf{D} \\
\mathbf{E} \\
\mathbf{F}\end{array}$ & $\begin{array}{l}y r s . \\
38 \\
36 \\
27 \\
27 \\
34 \\
35\end{array}$ & $\begin{array}{l}c m . \\
176 \\
171 \\
147 \\
168 \\
161 \\
149\end{array}$ & $\begin{array}{c}K \boldsymbol{g} . \\
74 \\
69 \\
51 \\
64 \\
62 \\
54\end{array}$ & $\begin{array}{c}\text { Kg. } \\
78.5 \\
95.5 \\
48.5 \\
59.5 \\
59.5 \\
45.5\end{array}$ & $\begin{array}{c}K_{g} . \\
69 \\
77 \\
43 \\
54 \\
53 \\
43\end{array}$ & $\begin{array}{r}1.06 \\
1.39 \\
.95 \\
.93 \\
.96 \\
.84\end{array}$ & $\begin{array}{r}\boldsymbol{K} \mathbf{g .} \\
9.5 \\
18.5 \\
5.5 \\
5.5 \\
6.5 \\
2.5\end{array}$ & $\begin{array}{c}\text { days } \\
29 \\
48 \\
17 \\
15 \\
14 \\
28\end{array}$ \\
\hline
\end{tabular}


a reduction measure and consumed his body fat at an estimated rate of $175 \mathrm{gm}$. per day.

Two aspects of the weight responses (Figure 3) are striking. The first is that the weight curve of each patient appears to proceed on a steady path from an initial to a final weight. The second feature, perhaps more impressive considering the diverse personalities represented, is the uniformity of the response seen when the curves of different patients are compared.

Both of these features may be discussed in more quantitative terms. After short term fluctuations are smoothed away it is found that each curve may be well described by a single exponential decay function. The fact that the mathematical form is simple rather than composite suggests that the weight change may be governed by a single dominant physiological process rather than by a number of unrelated occurrences.

The curves were analyzed as exponential functions and the data for each patient thus were condensed into two parameters: one gives the magni- tude of total weight change from initial to final steady state; the other gives a measure of the rate at which the final state is approached (i.e., the "half-time" of the process). When these parameters for different patients are compared with each other it is found that the magnitudes are quite different (Table II). Further study, however, shows that they are consistent if account is taken of the original state of nutrition, provided this is defined by the ratio between the patient's initial weight and his "ideal" weight calculated for height and age. In Figure 4 it may be seen that there is a satisfactory linear relation between the "initial state of nutrition," and each of the two parameters derived above. This leads to the interesting result that both parameters could be calculated in advance of an experiment and the average weight curve of a patient thus predicted for some three to six months into the future.

There can be little doubt that the period of metabolic transition must be at least as long as the time required for the weight to become steady.

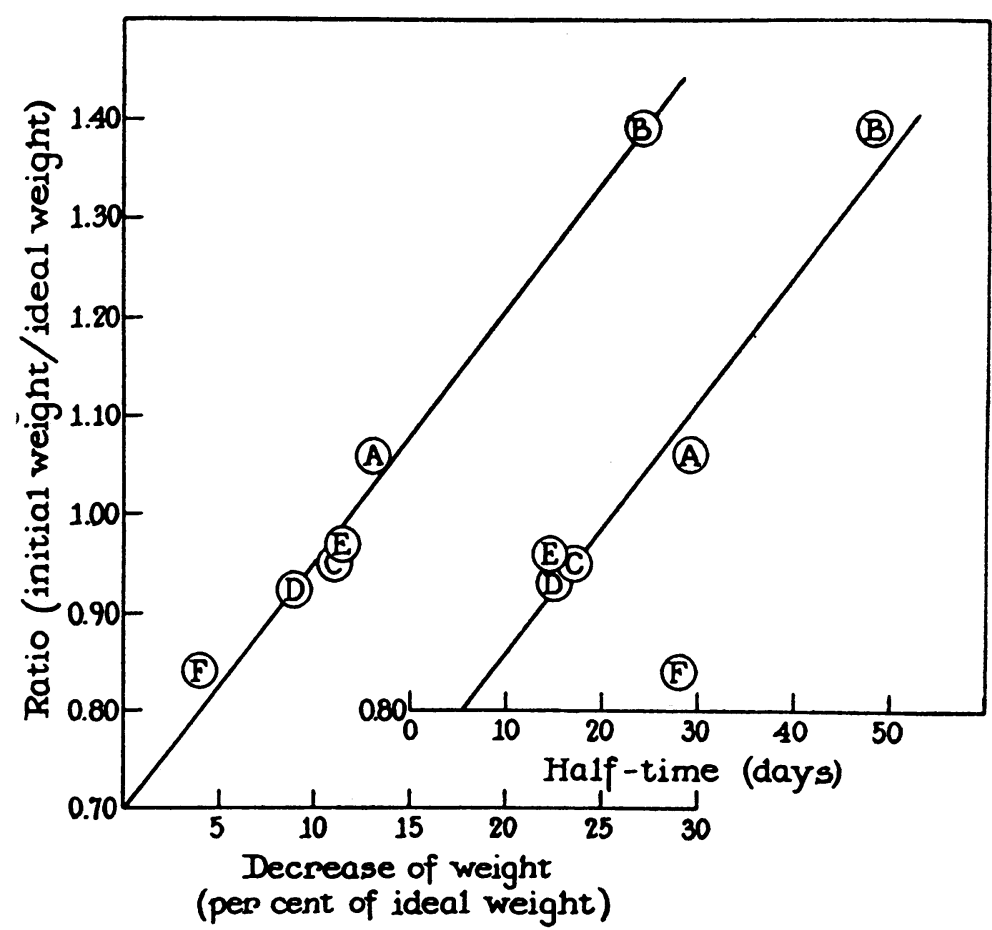

Fig. 4. Relation Between the Initial State of Nutrition (Ratio of Initial Weight to Ideal Weight) and the Two Parameters Defining the Weight Loss Curves: the Total. Decrease of Weight and the Half-Time of the Process

The letters in the circles refer each datum to the corresponding patient. 


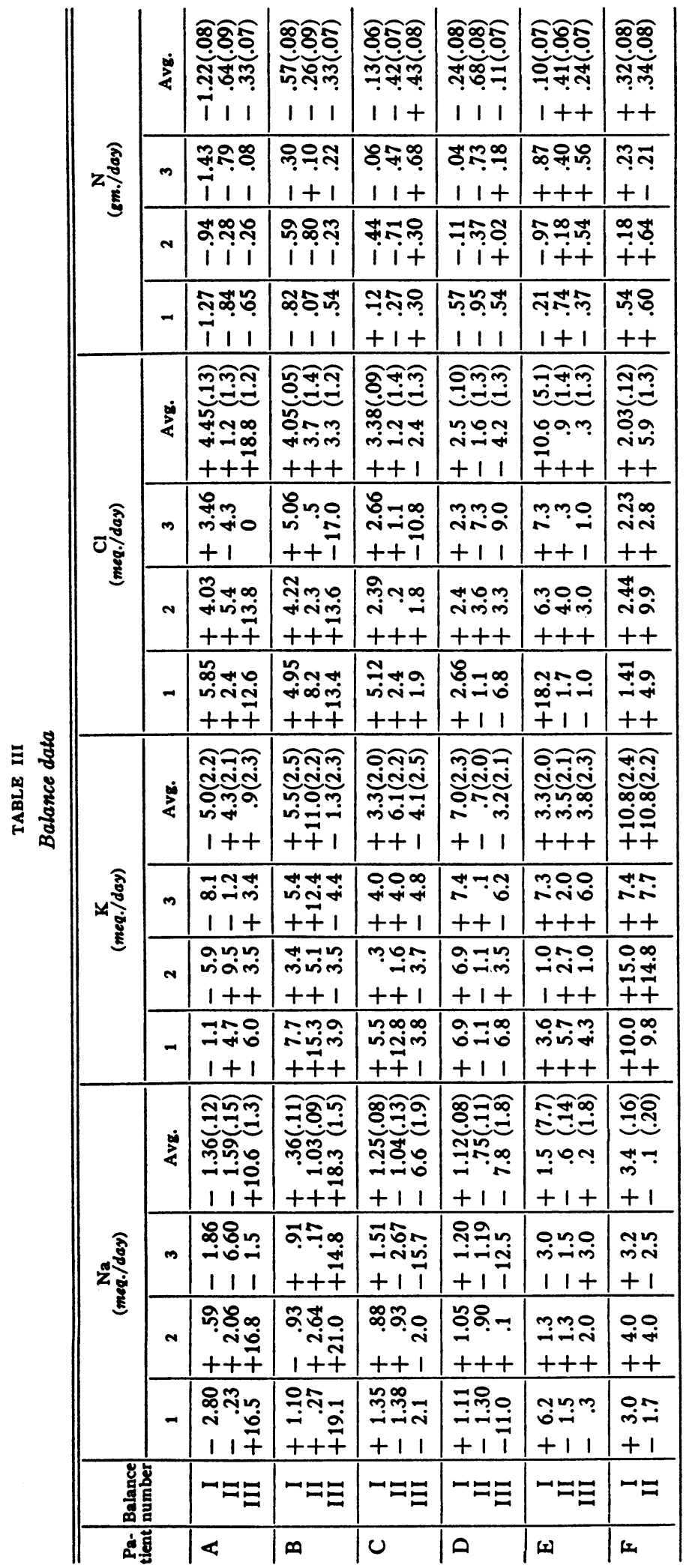


Evidence that the adaptation of nitrogen metabolism continued during the period of weight change will be presented in the next section.

\section{Nitrogen metabolism}

The data of Table III indicate that three patients ( $A, B, D)$ had not attained nitrogen equilibrium at the time of the last balance determination, while the three others $(C, E, F)$ were in balance. The subjects not in equilibrium at this time were the largest individuals; for them the fixed rice intake was relatively more limited and the degree of economy required for balance correspondingly greater.

In Table IV this fact is brought into evidence by an index labeled "urine N per basal calorie." This was calculated as a ratio between the average daily urinary nitrogen output and the basal meta- bolic rate expressed in calories per day. Balance II values are marked with an asterisk to indicate that the values were corrected by deduction of the ammonium chloride nitrogen ( $0.67 \mathrm{gm}$. per day) from the urinary excretion data before division by the metabolic rate. Since on a fixed diet the stool nitrogen excretion is approximately constant, it is possible to estimate the level of urinary nitrogen excretion at which a nitrogen balance of +0.25 gm. per day could be established, this figure being taken as an equilibrium value with allowance for the slight cutaneous nitrogen losses. The calculated excretion divided by the average measured basal metabolic rate of each patient yields the "equilibrium value of the urinary $\mathrm{N}$ per basal calorie." A low value of this index means that a subject must make a great reduction in his urinary nitrogen output relative to his total energy metab-

TABLE IV

Data used in discussion of nitrogen and mineral balances

\begin{tabular}{|c|c|c|c|c|c|c|c|c|c|c|c|c|c|c|c|c|c|}
\hline \multirow{4}{*}{$\begin{array}{c}\begin{array}{c}P a- \\
\text { tient }\end{array} \\
\mathrm{A}\end{array}$} & \multirow{4}{*}{$\begin{array}{c}\text { Period } \\
\\
\text { II } \\
\text { III }\end{array}$} & \multicolumn{12}{|c|}{ Average daily values } & \multicolumn{2}{|c|}{$\begin{array}{l}\text { Urine } \mathrm{N} \text { per } \\
\text { basal calorie }\end{array}$} & \multirow{3}{*}{$\begin{array}{l}\text { Hemo- } \\
\text { globin }\end{array}$} & \multirow{3}{*}{$\begin{array}{l}\text { Plasma } \\
\text { protein }\end{array}$} \\
\hline & & \multicolumn{4}{|c|}{ Intake } & \multicolumn{8}{|c|}{ Excretion } & \multirow{2}{*}{$\begin{array}{c}\text { Ob- } \\
\text { served }\end{array}$} & \multirow{2}{*}{$\begin{array}{c}\text { Equi- } \\
\text { librium } \\
\text { value }\end{array}$} & & \\
\hline & & $\mathrm{Na}$ & $\mathbf{K}$ & $\mathrm{Cl}$ & $\mathbf{N}$ & \multicolumn{2}{|c|}{$\underset{m e q}{\mathrm{Na}}$} & \multicolumn{2}{|c|}{$\underset{\text { meq. }}{\mathrm{K}}$} & \multicolumn{2}{|c|}{$\underset{\text { meq. }}{\mathrm{Cl}}$} & \multicolumn{2}{|c|}{$\underset{g m}{\mathrm{~N}}$} & & & & \\
\hline & & $\begin{array}{c}\text { meq. } \\
\\
2.43 \\
2.26 \\
45.4\end{array}$ & $\begin{array}{l}\text { meq. } \\
\\
52.0 \\
56.4 \\
57.2\end{array}$ & $\begin{array}{c}\text { meq. } \\
\\
6.13 \\
54.7 \\
48.7\end{array}$ & $\begin{array}{l}\text { gm. } \\
4.06 \\
5.22 \\
3.91\end{array}$ & $\begin{array}{c}U \\
.27 \\
.26 \\
23.0\end{array}$ & $\begin{array}{c}S \\
3.48 \\
2.64 \\
5.93\end{array}$ & $\begin{array}{c}\mathrm{U} \\
47.9 \\
42.0 \\
49.9\end{array}$ & $\begin{array}{c}S \\
8.2 \\
10.8 \\
7.0\end{array}$ & $\begin{array}{c}U \\
.58 \\
50.6 \\
37.7\end{array}$ & $\begin{array}{c}S \\
1.64 \\
2.23 \\
1.82\end{array}$ & $\begin{array}{c}\mathrm{U} \\
\\
3.94 \\
3.98 \\
2.63\end{array}$ & $\begin{array}{c}\mathrm{S} \\
1.29 \\
1.57 \\
1.47\end{array}$ & $\begin{array}{l}\begin{array}{l}\text { mg./ } \\
\text { cal. }\end{array} \\
2.37 \\
2.15^{*} \\
1.56\end{array}$ & $\begin{array}{c}\text { mg./ } \\
\text { cal. }\end{array}$ & $\begin{array}{c}g m . / \\
100 c c . \\
(15.1) \\
13.9 \\
12.6 \\
11.8\end{array}$ & $\begin{array}{c}g m . / \\
100 \text { cc. } \\
(7.6) \\
7.2 \\
7.6 \\
7.1\end{array}$ \\
\hline B & $\begin{array}{r}\text { I } \\
\text { II } \\
\text { III }\end{array}$ & $\begin{array}{l}2.94 \\
2.48 \\
45.5\end{array}$ & $\begin{array}{l}65.5 \\
59.3 \\
57.2\end{array}$ & $\begin{array}{c}6.57 \\
54.3 \\
48.7\end{array}$ & $\begin{array}{l}4.67 \\
5.28 \\
4.08\end{array}$ & $\begin{array}{r}.24 \\
.35 \\
22.6\end{array}$ & $\begin{array}{r}1.90 \\
.41 \\
1.01\end{array}$ & $\begin{array}{l}52.5 \\
42.8 \\
54.2\end{array}$ & $\begin{array}{l}8.1 \\
4.8 \\
5.2\end{array}$ & $\begin{array}{l}48.95 \\
43.7\end{array}$ & $\begin{array}{r}.91 \\
1.12 \\
1.26\end{array}$ & $\begin{array}{l}3.92 \\
3.92 \\
3.14\end{array}$ & \begin{tabular}{|l|}
1.23 \\
1.28 \\
1.10
\end{tabular} & $\begin{array}{l}1.85 \\
1.68^{*} \\
1.52\end{array}$ & 1.41 & $\begin{array}{c}(15.4) \\
15.2 \\
15.1 \\
14.2\end{array}$ & $\begin{array}{c}(7.7) \\
7.5 \\
7.6 \\
6.9\end{array}$ \\
\hline C & $\begin{array}{r}\text { I } \\
\text { II } \\
\text { III }\end{array}$ & $\begin{array}{r}2.47 \\
2.37 \\
45.4\end{array}$ & $\begin{array}{l}60.0 \\
60.7 \\
59.9\end{array}$ & $\begin{array}{c}4.41 \\
53.0 \\
47.0\end{array}$ & $\begin{array}{l}3.52 \\
3.43 \\
3.19\end{array}$ & $\begin{array}{r}.45 \\
.80 \\
47.6\end{array}$ & $\begin{array}{r}.37 \\
1.77 \\
3.71\end{array}$ & $\begin{array}{l}48.3 \\
45.5 \\
57.7\end{array}$ & $\begin{array}{l}7.7 \\
8.6 \\
6.1\end{array}$ & $\begin{array}{l}.61 \\
49.5 \\
47.4\end{array}$ & $\begin{array}{r}.73 \\
1.62 \\
1.73\end{array}$ & $\begin{array}{l}2.24 \\
2.62 \\
1.65\end{array}$ & $\begin{array}{l}1.24 \\
1.00 \\
1.00\end{array}$ & $\begin{array}{l}2.17 \\
1.84^{*} \\
1.49\end{array}$ & 1.61 & $\begin{array}{c}(13.2) \\
12.6 \\
11.5 \\
9.9\end{array}$ & $\begin{array}{c}(7.1) \\
6.4 \\
7.2 \\
5.4\end{array}$ \\
\hline D & $\begin{array}{c}\text { I } \\
\text { III }\end{array}$ & $\begin{array}{r}2.55 \\
2.04 \\
45.5\end{array}$ & $\begin{array}{l}60.1 \\
45.2 \\
54.2\end{array}$ & $\begin{array}{l}4.59 \\
51.6 \\
47.4\end{array}$ & $\begin{array}{l}4.38 \\
4.57 \\
4.00\end{array}$ & $\begin{array}{r}.65 \\
.83 \\
46.8\end{array}$ & $\begin{array}{r}.39 \\
.77 \\
5.97\end{array}$ & $\begin{array}{l}43.3 \\
34.5 \\
43.5\end{array}$ & $\begin{array}{r}9.5 \\
10.9 \\
11.4\end{array}$ & $\begin{array}{l}.98 \\
51.1 \\
48.5\end{array}$ & $\begin{array}{r}.84 \\
1.47 \\
2.79\end{array}$ & $\begin{array}{l}3.05 \\
3.51 \\
2.57\end{array}$ & $\begin{array}{l}1.51 \\
1.45 \\
1.43\end{array}$ & $\begin{array}{l}2.19 \\
1.85^{*} \\
1.80\end{array}$ & 1.58 & $\begin{array}{c}(11.8) \\
12.7 \\
12.6 \\
11.0\end{array}$ & $\begin{array}{c}(6.3) \\
6.2 \\
6.4 \\
5.7\end{array}$ \\
\hline $\mathbf{E}$ & $\begin{array}{r}\text { I } \\
\text { II } \\
\text { III }\end{array}$ & $\begin{array}{c}191 \\
2.59 \\
45.5\end{array}$ & $\begin{array}{l}58.8 \\
53.7 \\
58.0\end{array}$ & $\begin{array}{c}194 \\
52.2 \\
47.8\end{array}$ & $\begin{array}{l}4.18 \\
5.16 \\
4.11\end{array}$ & $\begin{array}{c}180 \\
1.53 \\
42.7\end{array}$ & $\begin{array}{c}7.2 \\
.42 \\
.54\end{array}$ & $\begin{array}{l}46.1 \\
45.1 \\
52.8\end{array}$ & $\begin{array}{l}8.5 \\
4.7 \\
5.1\end{array}$ & $\begin{array}{c}178 \\
49.5 \\
45.7\end{array}$ & $\begin{array}{l}3.18 \\
1.11 \\
1.39\end{array}$ & $\begin{array}{l}2.70 \\
3.08 \\
2.26\end{array}$ & $\begin{array}{l}1.47 \\
1.39 \\
1.45\end{array}$ & $\begin{array}{l}2.37 \\
2.11^{*} \\
2.07\end{array}$ & 2.15 & \begin{tabular}{|c}
$(10.8)$ \\
9.8 \\
10.0 \\
9.8
\end{tabular} & $\begin{array}{c}(6.9) \\
6.6 \\
6.9 \\
6.5\end{array}$ \\
\hline $\mathbf{F}$ & II & $\begin{array}{l}5.74 \\
5.60\end{array}$ & $\begin{array}{l}65.5 \\
60.7\end{array}$ & $\begin{array}{l}5.58 \\
53.7\end{array}$ & $\begin{array}{l}4.33 \\
4.41\end{array}$ & $\begin{array}{l}1.03 \\
3.72\end{array}$ & $\begin{array}{l}.91 \\
.86\end{array}$ & $\begin{array}{l}44.5 \\
43.5\end{array}$ & $\begin{array}{r}10.2 \\
6.2\end{array}$ & $\begin{array}{l}2.08 \\
45.4\end{array}$ & $\begin{array}{l}1.23 \\
1.62\end{array}$ & $\begin{array}{l}2.49 \\
2.90\end{array}$ & $\begin{array}{r}1.31 \\
.94\end{array}$ & $\begin{array}{l}1.76 \\
2.01 *\end{array}$ & 1.95 & $\begin{array}{c}(8.8) \\
8.2 \\
8.0\end{array}$ & $\begin{array}{c}(6.5) \\
7.3 \\
6.3\end{array}$ \\
\hline
\end{tabular}

Low intakes of sodium and chloride are italicized for emphasis. Asterisks indicate that the values were corrected by deduction of ammonium chloride nitrogen $(0.67 \mathrm{gm}$. per day) from urinary excretion data before division by metabolic rate. 
TABLE V

Water and caloric metabolism data

\begin{tabular}{|c|c|c|c|c|c|c|c|c|c|}
\hline Patient & Period & Basal & bolism & Diet & $\begin{array}{c}\text { Caloric } \\
\text { ratio } \\
\text { diet }\end{array}$ & $\begin{array}{c}\text { Total } \\
\text { water }\end{array}$ & $\frac{\text { Water intake }}{\text { Energy }}$ & $\begin{array}{c}\text { "Available } \\
\text { water" }\end{array}$ & $\begin{array}{l}\text { Plasma } \\
\text { volume }\end{array}$ \\
\hline A & II & $\begin{array}{l}B M R \\
-9 \\
-15 \\
-2\end{array}$ & $\begin{array}{c}\text { cal./day } \\
1660 \\
1550 \\
1690\end{array}$ & $\begin{array}{c}\text { cal./day } \\
2593 \\
2593 \\
2593\end{array}$ & $\begin{array}{l}1.56 \\
1.67 \\
1.53\end{array}$ & $\begin{array}{c}c c . / d a y \\
2240\end{array}$ & $\begin{array}{c}\text { cc. } / \text { cal } \\
86\end{array}$ & $\begin{array}{c}c c . / d a y \\
1000\end{array}$ & $\begin{array}{c}c c . / M^{2} \\
1410 \\
1380 \\
1540\end{array}$ \\
\hline B & II & $\begin{array}{l}+9 \\
+3 \\
+26\end{array}$ & $\begin{array}{l}2115 \\
1945 \\
2380\end{array}$ & $\begin{array}{l}1906 \\
1906 \\
1906\end{array}$ & $\begin{array}{l}.90 \\
.98 \\
.80\end{array}$ & 2825 & .80 & 1170 & $\begin{array}{l}1580 \\
1480 \\
1820\end{array}$ \\
\hline C & $\begin{array}{l}\text { I } \\
\text { II }\end{array}$ & $\begin{array}{l}-23 \\
-12 \\
-11\end{array}$ & $\begin{array}{l}1030 \\
1070 \\
1105\end{array}$ & $\begin{array}{l}2067 \\
1977 \\
1977\end{array}$ & $\begin{array}{l}2.01 \\
1.85 \\
1.79\end{array}$ & 2230 & 1.08 & 1260 & $\begin{array}{l}1310 \\
1320 \\
1430\end{array}$ \\
\hline D & $\begin{array}{l}\text { I } \\
\text { II } \\
\text { III }\end{array}$ & $\begin{array}{l}+5 \\
+6 \\
-3\end{array}$ & $\begin{array}{l}1530 \\
1550 \\
1430\end{array}$ & $\begin{array}{l}2387 \\
2387 \\
2387\end{array}$ & $\begin{array}{l}1.56 \\
1.54 \\
1.67\end{array}$ & 2310 & .97 & 1190 & $\begin{array}{l}1750 \\
1560 \\
1820\end{array}$ \\
\hline $\mathbf{E}$ & $\begin{array}{r}\text { I } \\
\text { II }\end{array}$ & $\begin{array}{l}-8 \\
-20 \\
-22\end{array}$ & $\begin{array}{l}1335 \\
1150 \\
1090\end{array}$ & $\begin{array}{l}2019 \\
2019 \\
2019\end{array}$ & $\begin{array}{l}1.51 \\
1.76 \\
1.85\end{array}$ & 2140 & 1.06 & 1190 & $\begin{array}{l}1630 \\
1030 \\
1500\end{array}$ \\
\hline F & II & $\begin{array}{l}+1 \\
-6\end{array}$ & $\begin{array}{l}1415 \\
1120\end{array}$ & 2210 & 1.56 & 2170 & .98 & 1130 & $\begin{array}{l}1570 \\
1540\end{array}$ \\
\hline
\end{tabular}

olism if he is to achieve nitrogen balance. It may be seen that Patients A, B and D had the lowest equilibrium value indices. Considered in this way the data suggest that the reason these patients had not attained equilibrium at the time of the last balance observations was the relatively greater metabolic economy necessary for their successful adaptation.

Continued adaptation of the nitrogen metabolism of all patients during the course of the three monthly balance studies is shown by the steady decrease in observed urine nitrogen output per basal calorie. Even the largest patients (A, B) had reduced this index almost to the equilibrium value at the time of the last balance study and most probably would have been able to effect the slight additional economy required if the study had been extended a few more months.

The two smallest patients $(C, F)$ on the other hand requested and were granted reduction in their daily rations of rice. Patient $C$ received 200 gm. per day in Balance I and $175 \mathrm{gm}$. per day in Balances II and III. Patient $\mathrm{F}$ was given $250 \mathrm{gm}$. per day in Balance I and $225 \mathrm{gm}$. per day in Balance II. The equilibrium values of "urine nitrogen per basal calorie" shown in Table III are calculated for these reduced intakes which even after reduc- tion are somewhat more liberal (higher indices) than the allowance of $250 \mathrm{gm}$. per day prescribed for the larger subjects. If these two smallest patients had continued to receive the full ration they could have attained nitrogen equilibrium with urinary excretion corresponding to the high indices of 2.60 and 2.30 , respectively.

In summary of the analysis so far it may be concluded that nitrogen balance may be attained on the rice-fruit diet, but that the time required for adaptation is measured in months, the longer times being required for the subjects with the greater caloric requirements and presumably the greater bulk of metabolizing tissue.

Independent evidence relevant to the state of protein economy may be taken from the blood protein concentrations (Table IV) which were approximately proportional to the total quantities in circulation since the plasma volumes suffered no major change (Table V). A relatively heavy demand was made on the subjects to regenerate blood taken for the numerous chemical determinations. Approximately one and a half liters of whole blood were taken during the five months of observation and in addition patients $C, D$ and $E$ had their normal menstrual losses. Despite this diversion all patients were able to maintain their plasma protein 
concentrations at normal levels. Hemoglobin was depressed. It is possible that this anemia was due to limitation of protein metabolism; more probably it resulted from iron deficiency. Only about $8 \mathrm{mg}$. per day (calculated) of iron was provided by the diet and even this small amount may have been rendered unavailable by the presence of about $150 \mathrm{mg}$. per day of phytic acid phosphorus calculated to have been included in the diet.

Finally it is of interest to compare the protein content of the present diet with that of other low protein diets reported to be minimal for support of nitrogen equilibrium. For this purpose the approximate daily ration of certain important amino acids will be calculated by means of the analytical data for rice given by Block and Bolling (9). The absolute values so calculated are rather uncertain, but comparison appears to be legitimate if the same tables are used for all of the estimates.

TABLE VI

Calculated amino acid intakes

\begin{tabular}{|c|c|c|c|c|}
\hline Amino acid & $\begin{array}{c}\text { (a) } \\
\text { Amount } \\
\text { from rice } \\
\text { intake of } \\
250 \mathrm{gm} \text {./day }\end{array}$ & $\begin{array}{c}\text { (b) } \\
\text { Loss by } \\
\text { blood } \\
\text { output } \\
\text { of } 7 \text { cc./day }\end{array}$ & $\begin{array}{c}\text { (c) } \\
\text { "Sufficient } \\
\text { values" } \\
\text { (from } \\
\text { literature) }\end{array}$ & $\frac{(a)-(b)}{(c)}$ \\
\hline $\begin{array}{l}\text { Arginine } \\
\text { *Histidine } \\
\text { * Lysine } \\
\text { Tyrosine } \\
\text { *Tryptophane } \\
\text { Phenylalanine } \\
\text { Cystine } \\
\text { Methionine } \\
\text { *Threonine } \\
\text { Leucine } \\
\text { Isoleucine } \\
\text { Valine }\end{array}$ & $\begin{array}{c}\text { (ms./day) } \\
1200 \\
250 \\
450 \\
950 \\
220 \\
1100 \\
220 \\
570 \\
660 \\
1300 \\
860 \\
1100\end{array}$ & \begin{tabular}{|c} 
(mg./day) \\
46 \\
71 \\
89 \\
40 \\
18 \\
71 \\
18 \\
14 \\
75 \\
190 \\
14 \\
72
\end{tabular} & $\begin{array}{c}\text { (ms./day) } \\
1200 \\
500 \\
800 \\
1000 \\
400 \\
1400 \\
200 \\
500 \\
1000 \\
1700 \\
1200 \\
1100\end{array}$ & $\begin{array}{l}.96 \\
.36 \\
.45 \\
.91 \\
.50 \\
.74 \\
1.01 \\
1.11 \\
.59 \\
.65 \\
.71 \\
.94\end{array}$ \\
\hline
\end{tabular}

* Intake low relative to value in column (c).

In Table VI are shown the amounts of amino acids calculated to have been supplied by $250 \mathrm{gm}$. of rice per day. Following this in column (b) is an estimate of the average daily loss of these amino acids through blood sampling at an average rate of 7 cc. per day. Column (c) gives apparently sufficient intakes of these amino acids. These values, taken from the literature (10), are based upon four low protein diets which had been found adequate for maintenance of nitrogen equilibrium in young adults; after adjustment of the data to the basis of $70 \mathrm{Kg}$. body weight by proportional variation the least daily intake of each amino acid was taken for the list. In the last column, the net intake of each amino acid [column (a) minus column (b)] is compared with the sufficient value by means of a ratio. It may be seen that for eight of the 12 amino acids the intakes are comparable. With respect to the four which appear low it should be noted that the rice data by neglect of fruit protein to some extent underestimate actual intakes and also that four minimal diets cannot be expected to determine limiting minimal allowances of all 12 amino acids. It is concluded that the observed attainment of nitrogen equilibrium on the rice-fruit diet is consistent with experience derived from study of low protein diets of dissimilar nature.

\section{Water metabolism}

It may be calculated from the data of Newburgh, Wiley and Lashmet (11) that about $0.47 \mathrm{cc}$. of water per calorie is expended for the dissipation of heat by subjects at comfortable temperatures. Deducting this value from the ratio of total water intake to energy consumption, shown in Table V, and then converting the remainder back to cubic centimeters per day, one obtains the estimate of water available for other purposes which is given in the last column. These values are of the same order of magnitude as the urine volumes, as they should be in the absence of visible sweat.

\section{Salt metabolism}

The balance data for sodium (Table III) may be analyzed from different points of view which depend on the time scale under consideration. As a short term matter, for periods not longer than a few months, the patients might be considered as being in sodium balance. On a long term basis the answer is less certain. In either case, the balance data must be interpreted with the reservation that sweat losses of sodium were not measured.

At the time of the first balance observation, two to three months after start of the rice-fruit diet, all patients but one had so limited their urinary and fecal sodium losses as to be in a positive balance. Only Patient $\mathrm{A}$ was in negative balance at this time and his average daily loss of $1.36 \mathrm{meq}$. per day appears to be negligible in relation to his probable body content of sodium. It would require almost four months steady loss at this rate to remove 
the sodium contained in one liter of extracellular fluid.

Conservation of body sodium was principally effected by reduction in urinary sodium output. The renal efficiency in performance of this task was shown by Patients $A$ and $B$ who had average daily urinary losses of only a quarter of a milliequivalent per day (Table IV). For such an accomplishment the thermodynamically calculated work is over 99 per cent of the theoretical minimum work for total reabsorption of sodium. Even Patient $\mathrm{F}$ who had chronic nephritis (proteinuria, casts, low fixed density, and urea clearance only 10 per cent normal) was almost able to maintain compensation on the low sodium intake of about 2 meq. per day. After about ten weeks of such restriction, however, her serum sodium concentration had fallen to 129 meq. per liter from an initial value of 144 meq. per liter, and it was decided to increase her margin of safety by a small increment in sodium allowance. Thereafter during the remainder of the study she received a supplementary 2.6 meq. per day which brought her sodium intake to the level of chloride intake. This extra ration, however, failed to protect her from the added demands of acid excretion imposed by ammonium chloride administered in Period II.

Ammonium chloride was given during Period II to provide a supplementary chloride dose of about 48 meq. per day. The amount was chosen to make the total chloride intake approximately. equal to the sum of sodium and potassium intakes. The fecal output of potassium, however, exceeded the fecal chloride loss by one to $10 \mathrm{meq}$. per day; therefore, despite the balance of these positive and negative ions in the daily ration, the kidney was required to eliminate a surplus of chloride at a time when maximal conservation of sodium was still required. All patients but $\mathrm{F}$ accomplished this without apparent difficulty, the only definite effect being a slight acid shift in the acid-base equilibrium of the blood plasma (Table VII) which remained within normal limits. Patient $F$ was unable to deal with the added stress of chloride load presumably because her damaged kidneys were unable to produce ammonia at the required rate. Unlike the other patients, she had a considerable increase in urinary sodium excretion during the second period (Table IV). She gradually be- came more acidotic over a period of three weeks, then rapidly became dehydrated and semicomatose. Sufficient sodium bicarbonate $(20 \mathrm{gm}$. in $1,500 \mathrm{cc}$. of water) and saline ( $500 \mathrm{cc}$.) were given to correct her acidosis and dehydration. She recovered from the ill effects of this episode in a few days and was returned to the rice-fruit diet nine days later.

In addition to the renal conservation of sodium, reduction of non-renal sodium loss was required

TABLE VII

Acid-base equilibrium

Acid-base data

\begin{tabular}{|c|c|c|c|c|c|c|c|}
\hline \multirow{3}{*}{$\underset{\text { tient }}{\text { Pa- }}$} & \multirow{3}{*}{ Period } & \multicolumn{4}{|c|}{ Plasma } & \multicolumn{2}{|c|}{ Urine $\mathbf{p H}$} \\
\hline & & \multicolumn{2}{|c|}{ Determined } & \multicolumn{2}{|c|}{ Calculated } & \multirow{2}{*}{11 a.m. } & \multirow{2}{*}{2 p.m. } \\
\hline & & $\underset{\text { content }}{\mathrm{CO}_{2}}$ & pH & $\mathbf{P C O}_{2}$ & $\mathrm{BHCO}$ & & \\
\hline $\mathbf{A}$ & 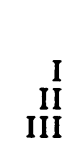 & $\begin{array}{c}\underset{\text { liler }}{m M /} \\
32.43 \\
25.29 \\
33.57\end{array}$ & $\begin{array}{l}7.40 \\
7.31 \\
7.38\end{array}$ & $\begin{array}{c}\text { mm. } \mathrm{Hg} \\
51 \\
50 \\
56\end{array}$ & $\begin{array}{c}\text { mM/ } \\
\text { liler } \\
30.6 \\
23.2 \\
31.5\end{array}$ & $\begin{array}{l}7.61 \\
5.46 \\
7.03\end{array}$ & $\begin{array}{l}6.59 \\
5.37 \\
6.75\end{array}$ \\
\hline B & 1 & $\begin{array}{l}32.09 \\
27.15 \\
33.27\end{array}$ & $\begin{array}{l}7.40 \\
7.37 \\
7.37\end{array}$ & $\begin{array}{l}50 \\
48 \\
56\end{array}$ & $\begin{array}{l}30.0 \\
25.2 \\
31.5\end{array}$ & $\begin{array}{l}7.18 \\
5.18 \\
6.55\end{array}$ & $\begin{array}{l}6.58 \\
5.15 \\
6.35\end{array}$ \\
\hline C & II & $\begin{array}{l}31.52 \\
25.49 \\
29.55\end{array}$ & $\begin{array}{l}7.41 \\
7.35 \\
7.37\end{array}$ & $\begin{array}{l}48 \\
46 \\
50\end{array}$ & $\begin{array}{l}28.8 \\
23.4 \\
28.0\end{array}$ & $\begin{array}{l}7.38 \\
5.38 \\
6.96\end{array}$ & $\begin{array}{l}7.00 \\
5.40 \\
6.03\end{array}$ \\
\hline D & III & $\begin{array}{l}30.78 \\
25.04 \\
29.79\end{array}$ & $\begin{array}{l}7.41 \\
7.31 \\
7.37\end{array}$ & $\begin{array}{l}47 \\
52 \\
50\end{array}$ & $\begin{array}{l}29.0 \\
23.2 \\
28.0\end{array}$ & $\begin{array}{l}5.92 \\
5.00 \\
6.63\end{array}$ & $\begin{array}{l}6.26 \\
5.25 \\
6.32\end{array}$ \\
\hline $\mathbf{E}$ & III & $\begin{array}{l}27.49 \\
28.53 \\
29.79\end{array}$ & $\begin{array}{l}7.32 \\
7.32 \\
7.37\end{array}$ & $\begin{array}{l}52 \\
58 \\
50\end{array}$ & $\begin{array}{l}25.8 \\
26.0 \\
28.0\end{array}$ & $\begin{array}{l}7.58 \\
5.13 \\
7.41\end{array}$ & $\begin{array}{l}7.26 \\
5.08 \\
7.25\end{array}$ \\
\hline $\mathbf{F}$ & III & $\begin{array}{l}30.47 \\
12.57 \\
32.56\end{array}$ & $\begin{array}{l}7.42 \\
7.20 \\
7.39\end{array}$ & $\begin{array}{l}46 \\
28 \\
52\end{array}$ & $\begin{array}{l}29.0 \\
11.8 \\
30.5\end{array}$ & $\begin{array}{l}6.83 \\
4.71 \\
6.70\end{array}$ & $\begin{array}{l}6.85 \\
4.70 \\
7.08\end{array}$ \\
\hline
\end{tabular}

for successful adaptation. Although normally the fecal output of sodium is quite negligible by comparison with the large surplus quantity of the element eliminated by the kidney, the situation becomes reversed with extreme limitation of intake. Almost all patients lost more sodium by the fecal than by the renal avenue (Table IV) and the one patient (A) who seemed to be in slight negative balance owed his position to a relatively large fecal sodium output. All patients showed an increase in fecal sodium related to the increased sodium ration of Period III. This fact suggests that there had been an actual adaptive reduction of fecal so- 
dium loss during the periods of low sodium consumption.

On a long term basis, the daily fluctuations of sodium balance must be considered, since the severe limitation of intake restricts the possible amplitude of positive variations in balance which would be required to compensate for occasional days of increased sodium loss. It might thus happen that a patient could remain in sodium balance for almost every day and yet become slowly depleted as a result of cumulative unrepaired losses of the occasional days. Even under the stable environmental condition of the metabolic ward the fluctuations of balance relative to intake were large during the low sodium periods (Table III). Variations of a milliequivalent per day in average daily balance were common and, since they were about ten times the magnitude expected on the basis of purely technical uncertainties, presumably reflected physiological changes. Fluctuations of this magnitude seem to be close to the limit at which long term net balance could be maintained if the daily supply of sodium available for retention is limited to about 2 meq. per day. It is of interest that with the higher sodium intake the variation of balance was about ten times as great. This suggests that one of the changes involved in adaptation to a low sodium intake is limitation of the cyclic physiological processes which cause variation in the body content of sodium.

In Period III the addition of sodium to the diet caused transient gains of weight (Figure 3 ). Complete retention of the 45 meq. per day sodium dose, if accompanied by sufficient water to make a solution of 140 meq. per liter concentration, would cause a weight gain of about $320 \mathrm{gm}$. per day. It may be seen in Figure 3 that the actual weight gains were approximately the same as this theoretical rate (shown as a dotted line) for a little more than a week. After a maximum gain of about 5 per cent of the body weights the patients spontaneously arrested the retention of fluid and tended to eliminate the accumulation. This elimination was not complete at the time of the last balance study: weights at the end of Period II had not in general returned to those of Period II and the plasma volumes were also somewhat greater (Table V). However, the downward slopes of the weight curves at the end of Period III suggest that further elimination of fluid might have been expected in a longer period. Hydration which attended increase of the dietary sodium allowance was thus only a temporary process; this suggests that the limitation of sodium intake had not led to any great reduction of body water content relative to the equilibrium value of body hydration on a more liberal sodium intake. Clinically, the return of hypertension and related findings were unrelated to this transient hydration effect.

Sweat sodium concentration also showed an adaptive change. All patients on the low sodium diet excreted less sodium than potassium (Table VIII) in the sweat of their forearms and hands. Two weeks after increase of the sodium intake from about 2 meq. per day to about 45 meq. per day without other change in program this relation was reversed in all but one instance.

TABLE VIII

Sweat concentrations

\begin{tabular}{c|c|c|c|c|c|c}
\hline \hline \multirow{2}{*}{ Patient } & \multicolumn{2}{|c|}{$\begin{array}{c}\text { Sodium intake about } 2 \text { meq. } \\
\text { per day }\end{array}$} & \multicolumn{2}{|c}{$\begin{array}{c}\text { Sodium intake about } 45 \text { meq. } \\
\text { per day }\end{array}$} \\
\cline { 2 - 7 } & $\mathrm{Na}$ & $\mathrm{K}$ & $\mathrm{Na} / \mathrm{K}$ & $\mathrm{Na}$ & $\mathrm{K}$ & $\mathrm{Na} / \mathrm{K}$ \\
\hline & meq./liter & meq./liter & & meq./liter & meq./liter & \\
$\mathrm{A}$ & 2.3 & 6.8 & .34 & 40.4 & 20.0 & 2.02 \\
$\mathrm{~B}$ & 10.5 & 25.0 & .42 & 2.8 & 13.6 & .21 \\
$\mathrm{C}$ & 30.2 & 39.2 & .77 & 36.5 & 22.2 & 1.64 \\
$\mathrm{D}$ & 38.6 & - & -7 & 45.6 & 31.6 & 1.45 \\
$\mathrm{E}$ & 11.2 & 14.4 & .78 & 56.7 & 27.4 & 2.07 \\
$\mathrm{~F}$ & 9.5 & 11.8 & .81 & - & - & - \\
\hline
\end{tabular}

Chloride balance data (Table III) showed an unexpected tendency for more marked positive balance of the element during the period low in both sodium and chloride than during the subsequent period which provided about ten times as much chloride. Sodium intake was the same in the two periods. This phenomenon of greater chloride retention in the low intake period was seen in four of five patients $(A, B, C, D)$. The exception (F) was the nephritic who developed serious acidosis in the high chloride period presumably from difficulty in renal excretion of the surplus chloride.

Although there was no detailed correlation of chloride balance with sodium balance there was a tendency for them to change in the same direction. No association between chloride and potassium balance was apparent. 
Adaptive reduction in the renal excretion of chloride (Table IV) was the most important conservative measure. Stool chloride output likewise was reduced during the periods of low chloride intake although only to a moderate extent so that this avenue of loss became an important component of the total balance. In both these respects chloride resembled sodium. All patients continued to have free gastric hydrochloric acid by the usual clinical test during the period of low chloride intake. So far as one can reason from this incomplete evidence, it might be taken to suggest that the adaptive reduction in fecal chloride loss was due to increased recovery of chloride from the intestinal juices rather than depressed secretion.

Potassium balance was found to vary as much as 5 meq. per day without definite relation to the balance values for sodium, chloride or nitrogen. Such variation, since it was only about twice the standard deviation calculated as probable on the basis of purely technical causes, may have been apparent and not due to physiological changes. The theoretical relation between potassium and nitrogen balances, based on the expectation that two elements should tend to be gained or lost in the same proportion as found in protoplasm, requires only 2.7 meq. of potassium to be associated with $1.0 \mathrm{gm}$. of nitrogen (12). Such an amount of potassium is too small in relation to the probable technical fluctuation to be apparent in the date.

Serum concentrations of sodium, potassium and chloride were measured in all patients at intervals of one to two weeks throughout the study. Significant changes in these values were observed only in the case of Patient $F$ who had impaired renal function. Her serum sodium concentration fell steadily from a pretreatment value of 144 meq. per liter to 129 meq. per liter during the first ten weeks of rice diet and during the next month continued to decline to 124 meq. per liter despite a supplementary sodium ration (3 meq. per day). Concurrently her serum chloride concentration was reduced from 103 to 88 meq. per liter. All other patients remained in the normal ranges.

\section{DISCUSSION}

The clinical observations showed objective improvement in five of the six patients under treatment with the rice-fruit diet on a metabolic ward.
In agreement with the findings of others (13) it was observed that sodium, but not chloride, restriction was necessary for the therapeutic effect.

There exists a disagreement in the literature as to the sufficiency of the rice-fruit diet for nitrogen balance. Two reports $(14,15)$ indicate that it is adequate; two others, that it is not $(16,17)$. The present data support the conclusion of the first group and suggest an explanation for the discrepancy, namely, that the observations of the latter workers were made while adaptation was incomplete. The phenomena that follow a sudden change of the dietary intake may be divided into the transient and the steady state effects. Whether the condition of the system at some later period of observation is dominated by one or the other of these depends on the length of time required for decay of the transients. Weight loss and negative nitrogen balances, which are transient effects, persisted in the larger subjects for at least three to five months after change of diet.

Adaptation of sodium and chloride metabolism appears to be more rapid. Decay of the transient negative balances after reduction of intake appears to be substantially completed in a relatively few days. Thus a patient if studied during the first few weeks after the change to the rice-fruit diet will probably be found to be in negative balance with respect to nitrogen but in normal balance of sodium.

Despite the limitation of sodium intake there was no apparent depletion of extracellular water or of fixed base in any of the five patients with normal function. The one patient who had renal limitations ( $F$ ) developed a nearly fatal acidosis during the period of ammonium chloride supplement. It is of interest that this extreme depletion of her body sodium not only failed to relieve her hypertension but actually increased her blood pressure, caused enlargement of the heart and return of inverted $\mathrm{T}$ waves in the electrocardiogram. $\mathrm{Re}$ sults consistent with this phenomenon were reported by Stead and his associates (18) who obtained the best clinical responses to low sodium diet among the benign hypertensive patients with good renal function, while those with damaged kidneys tended to become depleted and also showed little or no reduction of blood pressure.

Another consideration that suggests a mode of therapeutic action other than depletion is that 
three patients (A, C, E) experienced a reduction of blood pressure to the normal range but did not continue to fall to hypotensive levels. If the fall of pressure had been due to a non-specific depression one might expect that reduction of the blood pressure below normal would have been encountered in some cases.

This separation of effects of the dietary change into transient and steady state aspects has relevance to the problem of how the rice-fruit diet helps some hypertensive patients. In the studies here reported, the observations were extended over a period sufficiently long to allow adaptation to approach completion. With this extension of time, the beneficial effects of the diet were not lost; on the contrary, clinical benefit was seen in some only after a number of weeks.

The interpretation which seems to be most probable is that the beneficial effect of a low sodium diet derives from the steady state adaptive response induced by the limitation. On this basis the therapeutic aim should be reduction of the sodium intake to a level which approaches, but does not fall below, the minimum required for long term maintenance.

\section{SUMMARY}

1. Six patients with relatively uncomplicated hypertension were treated with the rice-fruit diet of Kempner during a six month residence on the metabolic ward. Five of the six showed objective clinical improvement as evidenced by significant reduction in mean blood pressures, associated decrease in heart sizes, improvement in fundi and return to normal of low or inverted electrocardiographic $\mathrm{T}$ waves.

2. Restriction of sodium, but not of chloride, appeared to be necessary for the clinical effect.

3. An investigation was made of the sufficiency of the diet for maintenance as shown by the attainment of :

a) Steady weight.

b) Balance with respect to nitrogen, sodium, potassium and chloride.

c) Normal serum electrolyte concentrations.

4. The five patients with normal renal function appeared to reach, or to approach closely, equilibrium with the diet. The sixth, who had impaired kidneys, achieved the first two of the criteria but probably became slowly depleted of body sodium, despite apparent balance, since her serum concentrations were reduced. With the added burden of ammonium chloride administration she developed severe dehydration and acidosis.

5. Adaptation proceeded slowly. Three months were required for attainment of steady weight by the smallest subjects and a little more than five months would have been required by the largest.

6. Since the clinical benefit of the diet did not appear to be associated with depletion but, on the contrary, with successful adaptation, it was suggested that the therapeutic effect is a consequence of the steady state adaptive response to limitation of sodium intake.

\section{CLINICAL HISTORIES}

A (RIH No. 12,390), a 39 year old policeman, was well until one year before admission when he experienced four episodes of paroxysmal nocturnal dyspnea associated with sharp pressing pain which radiated from the sternum to the costovertebral angles. Hypertension was discovered at this time. Subsequently he began to have exertional dyspnea, frequent frontal headaches, nervousness and irritability. There were no other neurological or any visual symptoms. Weight and appetite remained unchanged. Renal history was negative except for nocturia once per night during the preceding seven months. The patient's father died of hypertension when 54 years old.

Physical examination was negative except for elevation of blood pressure $(210 / 130)$ and enlargement of heart. Fundi presented narrow arteries but no hemorrhages, exudates or papilledema. Blood hemoglobin concentration was $15.4 \mathrm{gm}$. per $100 \mathrm{cc}$; plasma proteins, $8.19 \mathrm{gm}$. per $100 \mathrm{cc}$; and white cell count, 9,000 with normal smear. Urine examination was negative. Urea clearance was $103 \mathrm{cc}$. per minute, equal to 144 per cent of normal for his surface area.

$B$ ( $R I H$ No. 12,398), a 36 year old salesman, was told that he had high blood pressure 15 years before admission but being asymptomatic he ignored the report. Nine years later he was rejected for military service because of hypertension. His first symptom was a transient attack of left sided paresthesia three years before admission. A year later he experienced a similar attack; the third episode six months before entry involved the right side and was accompanied by an aphasia lasting a few hours. Headaches became more frequent. There were no cardiac or renal symptoms. The patient's mother, age 60 , and two sisters, 26 and 33 years old, were said to have high blood pressure.

Physical examination showed an obese man (height 171 cm., weight $97.6 \mathrm{Kg}$.) who looked older than his stated age. Heart was enlarged; blood pressure, 240/150. In the fundi, several foci of exudate were observed with two 
fresh hemorrhages, narrow tortuous arteries and nasal blurring of the discs without papilledema. Neurological examination was negative. Blood hemoglobin concentration was $13.8 \mathrm{gm}$. per $100 \mathrm{cc}$; plasma proteins, 7.35 gm. per $100 \mathrm{cc}$; white cell count, 8,200 with smear normal. Urine showed a moderate number of casts but no red or white cells in the sediment and no proteinuria. Urea clearance was $66 \mathrm{cc}$. per minute, equal to 88 per cent normal for his surface area.

C (RIH No. 12,385), a 27 year old housewife, in the last trimester of her third pregnancy observed swelling of her legs and was found to have high blood pressure. She was given a low salt diet with benefit and in due time had a normal delivery. During the three years that intervened before admission she felt weak, barely able to do her housework, had frequent headaches, nausea, lightheadedness and occasional sense of pressure over the precordium unrelated to exertion. There was moderate exertional dyspnea with evening edema of feet; no orthopnea, paroxysmal dyspnea or anginal attacks had appeared. Urine volume seemed to her excessive; burning, pyuria and hematuria had not been noticed. The patient's father died of "Bright's disease" at 50 years of age.

Physical examination revealed a blood pressure of 230/ 130 at the time of first examination and $160 / 100$ on the day of admission to the hospital. Heart was negative except for enlargement. Neurological examination was negative. Fundi showed several hemorrhages and foci of exudate, and moderate blurring of the nasal margins of the discs.

Blood hemoglobin concentration was $11.3 \mathrm{gm}$. per 100 cc.; plasma proteins, $5.8 \mathrm{gm}$. per $100 \mathrm{cc}$; white cell count, 10,800 with normal smear. Urine contained one plus protein, with a moderate number of casts in the sediment. Culture of urine was negative. Urea clearance was 42 cc. per minute, equal to 67 per cent normal for her surface area.

$D$ (RIH No. 12,392), a 27 year old secretary, knew that her blood pressure had been elevated for at least seven years. She was asymptomatic until the onset two years before admission of frequent headaches and a tendency to cry easily with little cause, which she considered a distinct change in her personality. On a few occasions she experienced transient pain in the substernal region and in both wrists while walking against the wind in cold weather. She had had no dyspnea, edema, renal symptoms or evidence of focal neurological trouble.

On physical examination, a blood pressure of $240 / 140$ was found, but the heart size was within normal limits. A grade one apical systolic murmur was present with accentuation of A2; no gallop or friction rub was heard. Neurological examination was negative. Fundi showed one area of hemorrhage and exudate, spasm of arteries, occasional A-V compressions and blurring of the medial margin of the left disc without papilledema. Blood hemoglobin concentration was $12.6 \mathrm{gm}$. per $100 \mathrm{cc}$; plasma proteins, $6.5 \mathrm{gm}$. per $100 \mathrm{cc}$; white cell count, 4,500 with normal smear. Urine contained one plus protein with negative sediment. Urea clearance was $74 \mathrm{cc}$. per minute, equal to 100 per cent normal for her surface area. A negative result was obtained in a test for pheochromocytoma using benzodioxane $933 \mathrm{~F}$ as described by Goldenberg and associates (19).

E (RIH No. 12,377), a 34 year old colored housewife, had been found to have elevated blood pressure five years before admission. She remained asymptomatic during the following three years, during which time she had an uneventful pregnancy. In the last two years of the interval she was troubled by frequent pressure-like headaches associated with nervousness and a choking sensation. There was sufficient domestic stress at this time to account for the symptoms. No other symptoms appeared. One brother had high blood pressure.

On physical examination her blood pressure was 220/ 130 ; the heart was enlarged but otherwise not remarkable. In the fundi a few small hemorrhages were found; the vessels and discs appeared normal. Blood hemoglobin concentration was $11.3 \mathrm{gm}$. per $100 \mathrm{cc}$; plasma proteins, $6.7 \mathrm{gm}$. per $100 \mathrm{cc}$. and white count, 3,700 with normal smear. The urine was negative except for a few granular casts in the sediment obtained by concentration. Urea clearance was 73 cc. per minute, equal to 104 per cent normal for her surface area.

$F$ (RIH No. 12,380), a 35 year old ex-dancer, was the only patient of the group with impaired renal function. The onset of her illness could not be dated; for many years she had suffered from frequent headaches but she had not been aware of hypertension until informed by a physician who was consulted for the headaches three years before admission. Subsequently she developed marked dyspnea on climbing a short flight of stairs and had attacks of palpitation with variable sharp chest pains. Nocturia (five to six times per night) had been present for the preceding three years; hematuria had been observed. Most disturbing to the patient was the marked decrease in visual acuity during the year just past, progressing to almost total loss of vision bilaterally six weeks before admission. One year before admission the patient had had her left adrenal gland and celiac ganglion removed at another hospital. Her mother died at 53 of high blood pressure; two brothers died at ages 23 and 40 with heart touble.

Physical examination revealed a blood pressure of 240/120. Heart was enlarged; rhythm was regular; rate, 96; no murmur, gallop or friction rub was heard. Neurological examination was negative. Fundi showed numerous areas of old and new hemorrhages and exudates, marked arteriovenous nicking, marked blurring of the discs without measurable elevation, spastic arteries and a large pigmented area around the left macula. Large print could be read with difficulty. Blood hemoglobin concentration was $9.6 \mathrm{gm}$. per $100 \mathrm{cc}$; plasma protein, 6.7 gm. per $100 \mathrm{cc}$; white count, 7,000 with normal smear. Urine had a density of 1.007 , contained one plus albumin; a few red cells, white cells and granular casts were seen in the sediment obtained by centrifugation. Urea clearance was $11 \mathrm{cc}$. per minute, only 17 per cent of the normal value for a person of her surface area. 


\section{BIBLIOGRAPHY}

1. Kempner, W., Treatment of kidney disease and hypertensive vascular disease with rice diet. North Carolina M. J., 1944, 5, 125, 273.

2. Chapman, C. B., and Gibbons, T. B., The diet and hypertension. Medicine, 1949, 29, 29.

3. Hiller, A., Plazin, J., and Van Slyke, D. D., A study of conditions for Kjeldahl determination of nitrogen in proteins. J. Biol. Chem., 1948, 176, 1401.

4. Sendroy, J., Jr., Microdetermination of chloride in biological fluids, with solid silver iodate. II. Titrimetric analysis. J. Biol. Chem., 1937, 120, 405.

5. Van Slyke, D. D., and Hiller, A., Application of Sendroy's iodometric chloride titration to proteincontaining fluids. J. Biol. Chem., 1947, 167, 107.

6. Peters, J. P., and Van Slyke, D. D., Quantitative Clinical Chemistry. Vol. II. Methods. The Williams \& Wilkins Co., Baltimore, 1932, p. 283.

7. Gregersen, M. I., A practical method for the determination of blood volume with the dye T-1824; Survey of present basis of dye-method and its clinical applications. J. Lab. \& Clin. Med., 1944, 29, 1266.

8. Fisher, R. A., Statistical Methods for Research Workers. Oliver \& Boyd, Ltd., 1944, 9th Ed., p. 116.

9. Block, R. J., and Bolling, D., The Amino Acid Composition of Proteins and Foods: Analytical Methods and Results. Charles C. Thomas, Springfield, Ill., 1945.

10. Harte, R. A., and Travers, J. J., Human amino acid requirements. Science, 1947, 105, 15.

11. Newburgh, L. H., Wiley, F. H., and Lashmet, F. H.,
Method for determination of heat production over long periods of time. J. Clin. Invest., 1931, 10, 703.

12. Reifenstein, E. C., Albright, F., and Wells, S. L., The accumulation, interpretation and presentation of data pertaining to metabolic balances, notably those of calcium, phosphorus, and nitrogen. J. Clin. Endocrinol., 1945, 5, 367.

13. Grollman, A., Harrison, T. R., Mason, M. F., Baxter, J., Crampton, J., and Reichsman, F., Sodium restriction in the diet for hypertension. J. A. M. A., 1945, 129, 533.

14. Kempner, W., Compensation of renal metabolic dysfunction. Treatment of kidney disease and hypertensive vascular disease with rice diet. North Carolina M. J., 1945, 6, 61, 117.

15. Peschel, E., and Peschel, R. L., Nitrogen balance on rice diet. J. Clin. Invest., 1950, 29, 455.

16. Schwartz, W. B., and Merlis, J. K., Nitrogen balance studies on the Kempner rice diet. J. Clin. Invest., 1948, 27, 406.

17. Currens, H., Reid, E. A. S., MacLachlan, E. A., Terry, M. L., Butler, A. M., and White, P. D., Physiologic, metabolic and electrolyte balance studies of hypertensive patients while on the rice diet. J. Clin. Invest., 1949, 28, 776.

18. Stead, W. W., Reiser, M. F., Rapoport, S., and Ferris, E. B., The effect of sodium chloride depletion on blood pressure and tetraethylammonium chloride response in hypertension. J. Clin. Invest., 1948, 27,766 .

19. Goldenberg, M., Snyder, C. H., and Aranow, H., Jr., New test for hypertension due to circulating epinephrine. J. A. M. A., 1947, 135, 971. 